\title{
An Attempt to Calculate the Number of Inhabitants in Relation to the Social Dimension in Neo-Babylonian Residential Architecture on the Example of Babylon
}

\section{Introduction}

The article attempts to reconstruct the approximate number of residents of households from the Neo-Babylonian period. The example of the ancient city of Babylon was chosen due to the good condition of the households and the continuity of architectural features and residential traditions from antiquity till the present day. In the first part, I discuss the characteristic features of NeoBabylonian households. In the second part, based on ethnographic sources, ways of adapting the household to the needs of its residents are presented. In the third part, an analysis regarding the calculation of the number of residents in a household based on the surface area was undertaken.

The three main residential areas date back to the first millennium BC and were discovered in southern Mesopotamia: in the area of Merkes in Babylon (Reuther I926: 77-I22), in Ur (Woolley, Mallowan 1962: 43-48) and Uruk, in the west and southwest of the temple of Eanna. The article will discuss is examples of households: I2 households from the Merkes area, one household al-Bayati (al-Bayati 1985: I13-II6) located to the west of the Greek theatre and the Ishtar temple, 2 households (E-I, E-2) (Wetzel, Weissbach 1938) located near the gate of the $4^{\text {th }}$ temenos of Etemenanki.

The households of the Merkes area are usually much larger than ordinary households built during this period. They range in size from about Ioo to over Iooo square metres while a standard household has an average area of 
approximately $400 \mathrm{~m}^{2}$ (Miglus 1999: 307-310). The overall location of the residential area in relation to the city plan was the same as in previous periods ${ }^{\mathrm{I}}$ in Babylonian cities, i.e. within the inner-city walls ${ }^{2}$. The Neo-Babylonian households had one or two main entrances, most of which opened directly onto the main street. A characteristic feature which they shared was the central courtyard, which was the main source of ventilation and provided light throughout the household. All rooms whose walls surround the courtyard had thicker "partition" walls which was beneficial as it ensured better thermal insulation. There were also examples of households which had more than one courtyard, which may indicate that they served as multi-family households ${ }^{3}$, or had an economic function as in the case of household IV ${ }^{4}$.

The main salon stood out with its dimensions as the largest room among all rooms. It was always located on the south side of the courtyard to avoid and reduce light falling in parallel during sunrise and sunset. Often the main living room was surrounded by smaller rooms: a bedroom in the south and a bathroom or toilet from the east or west. Those rooms constituted the main salon in the household. The number of living rooms depended on the number of courtyards, and each courtyard had its own apartment in its southern part.

In order to maintain privacy, the main entrance to the household was placed on the opposite side of the residential part of the household (courtyard and main living room), or other rooms separated them. Sometimes near the entrance was the so-called reception room which separated the courtyard from the main salon (see Fig. I4, room 5).

\section{The Household}

Archaeological research alone cannot provide complete information on the operation of households, there it is important to use ethnographic data to reconstruct the functionality of the home. The attempt to determine the relationship between the surface of households and the number of inhabitants is based on many cultural and biological factors. The difficulty lies in the precise determination of the home development cycle and the proper recognition of the possible effects of changes to the household plan in the archaeological record.

I As for example, in the Old Babylonian period (I800-I595 BC).

2 See city plan of Babylon (Merkes area).

3 In my opinion, each courtyard with a main salon belonged to one family.

4 The texts from the temple archives demonstrate that small craft production could take place in residential households. For more on this topic, see Castel (1992); Baker (20I0). 
According to P. Laslett (1972) and H.D. Baker (20ro), a "household" is defined as a "roommate housing unit". Based on their research, we can divide the household into the following types:

1. The "simple nuclear family" consists of parents and their children, without slaves5.

2. A "family conjugal unit" consists of a marriage without children or one widowed spouse with children and with or without slaves.

3. The "extended household" consists of a "family conjugal unit" with additional family member(s) and with or without slaves.

4. A "multiple household" consists of more than one "family conjugate unit" joined by marriage or kinship.

Families consisting of small cells were led by the head of the family. As stated by Marten Stol: in the first half of the first millennium BCE, monogamy was the norm in Mesopotamia, and a marriage could only be annulled when the previous spouse had agreed to it or if the wife had not given birth to children (Stol 1995: 488-489). It was unusual for families to have more than five children living together at the same time. One of the reasons for this was the high mortality rate among children (Matthews 2003: 2I), while life expectancy at this time was around 50-60 years (Castel 1992: IO2; Tenney 2010: I40) ${ }^{6}$.

The distinguishing features of the four household types that developed in response to different conditions and directly affected the lifestyles of inhabitants can be described through reference to ethnographic sources and described as follows (Baker 20Io):

1. Division of inheritance.

2. The need for physical division within the household. An example is household II, in which a new main entrance was built because of the newly built household III, which blocked the old entrance to household II (see illustrations; Reuther 1926).

3. Household rental. Written documents can provide substantial evidence indicating a variety of joint ownership scenarios. From these, it can be determined that the whole household (or part of it) was rented. Households II, III, IV, X and al-Bayati (see illustrations) can serve as good examples of rental practice. Rental may occur in homes that have more than one main living room (bit iltäni) and more than one courtyard (tarbașu $)^{7}$.

5 Schloen claims that for the entire first millennium BC in Levant, most households consisted of a simple nuclear family (Schloen 200I: 125).

6 Other examples are classified by scholars based on ethnographic texts as follows: 40 - beginning of life, 50 - short life, 60 - maturity, 70 - long life, 80 - old age, 90 - extreme old age (see Gurney, Hulin 1964; Sjöberg 1974).

7 For more details on Babylonian terminology describing the rooms of the household versus functions, see Baker (2015). 
4. The division between various sides, when the household is inhabited by more than one family who are related to each other, without the introduction of any modifications to the household plan.

After analysing these factors, no clear correlation can be found between the size of the households and the number of families. It should also be taken into account that slaves lived in the same household ${ }^{8}$. Considering the size of the property, it must be remembered that the number of inhabitants does not have to correspond to the area of the entire household. Therefore, it can be assumed that the size of the household indicates the status of the family in the social hierarchy. It should be noted that in the light of current research, it is uncertain whether the hierarchical family structure in question was the same in all regions and whether it affected all social groups.

\section{Methods for Calculating the Number of linhabitants Using Residential Areas}

The methods for calculating the number of inhabitants in a residential home have been analysed by many researchers (including Fakri 198r; Kolb et al. 1985). In this approach, the results of considerations by the American cultural anthropologist, R. Naroll (1962), were adopted. Based on research in eighteen societies from four continents, he proposed $\mathrm{Io}^{2}$ as an average living space for one person. This is described by the following formula:

$$
\text { POPULATION }=\text { AREA } / \text { IO } \text { M }^{2} \text { (NAROLL'S CONSTANT) }
$$

Steven LeBlanc proposed calculating the required area for one person, taking into account only sheltered living spaces in the household (without public spaces) (LeBlanc 1971: 210). Considering these assumptions, the compiled data for three cultural regions (Samoa, Iran, South America) assume values from 7 to $10 \mathrm{~m}^{2}$ per person (Pfälzner 20or: 28). For military camps, it is estimated that this space is much smaller and ranges from 2 to $4 \mathrm{~m}^{2}$. As for the application of the above formula for archaeological data, the residential area should be distinguished from the storage space and the separate area occupied by animals, and take into account all parts of the building or rooms that were used at that time.

S. Cassellberry stated that calculations for culturally diverse areas do not include types of households, and the number of square meters per person is not determined biologically, but culturally (Casselberry 1974: II7-I22). He rejected the general

8 Baker (20I0: I84) quotes an example where slaves lived with their masters. 
calculation of the number of inhabitants and suggested setting appropriate values for each specific type of household. For large open households, inhabited by many families, he accepted an average of $15 \mathrm{~m}^{2}$ per person. For example, for Aliabad in Iran, an average area of Io $^{2}$ can be counted per person in multi-family households for basic and extended families, while in Hasanabad for the same type of household, this area is approx. $7.3 \mathrm{~m}^{2}$. In both cases, the calculations were carried out taking into account only the surface of indoor living spaces. At Tall I-Nun in Iran, there are larger fluctuations in population density and type of households - in former villages, the population density was $33 \mathrm{~m}^{2}$ per person, while in modern villages it is approximately $200 \mathrm{~m}^{2}$ (in both cases these values apply to the general area of the household). For roofed areas of households with high performance standards discovered in $\mathrm{i}-\mathrm{Nun}$, this value reaches $\mathrm{II} \mathrm{m}^{2}$ in former villages and $30 \mathrm{~m}^{2}$ in the cities of today. Ethnographic research indicates that the demand for living space varies even within one geographical region. This can be demonstrated from a comparative analysis of pueblo settlements located in south-western America. Households in tightly built-up estates are larger than households in areas with loosely placed buildings, although not many residents live there (Pfälzner 200I: 29). The size of living space per person increases in densely built-up settlements. However, fluctuations in size do not depend only on economic, cultural or existential factors. K. Dohm (1990) demonstrated that a higher population density in sediments increases the need for privacy.

A great deal of archaeological research has focused on determining the number of inhabitants based on excavations of households. It is generally accepted that nuclear families lived in small households, and extended families lived in larger buildings, which in turn allows the approximate number of inhabitants to be determined per square meter of the living space of the household. The main concern turns out to be the relationship between the number of inhabitants, the size of the household and their linear increase relative to the area of the household. Depending on the model, it is assumed, for example, that the average area that an inhabitant could occupy is $5.9 \mathrm{~m}^{2}$ per adult according to P. Wiessner (1974). S.F. Cook and R.F. Heizer, who studied the Aboriginal society, assumed the value of $6 \mathrm{~m}^{2}$ per inhabitant, and additionally, the observed deviation was about $3 \mathrm{~m}^{2}$ (Cook, Heizer 1968: I02).

To make calculations possible, the research and the difficulty in estimating the total area of the household must be considered in cases where the working and living areas are not equal. One should also remember that in rural areas, up to $54 \%$ of the total area of the household was reserved for animals, while the living area was only about $35 \%$ of this value (Fakri 1981: 74). Furthermore, to validate the results, it is worth considering the climatic conditions, which means that in areas with a hot climate, many tasks could be performed outside. However, the 
above factors depend on the type of population studied, the size of the assumptions and the potential mobility of the population (Castel I992: IOO).

The extent to which people interact with their environment can also have an impact on the management of space. Many authors claim that these factors can only be effectively analysed at the regional level (Castel 1992: 100) due to significant differences in local conditions that interfere with modelling.

As shown in ethnographic research, there are many settlement models that usually result from the characteristics of a given society and its culture. It is difficult to use the concept of linear dependence of the population in the household space, because the expansion of the household does not have to involve an increase in the number of its inhabitants, with the exception of the need to adapt the building to the appearance and architectural requirements of the environment.

Reconstruction of social structures can often be the result of fragmentary excavations - for example, the wealth of the inhabitants of Ur corresponds to the material status of people living in Babylon (Woolley, Mallowan 1962: 46-47). Many studies have ignored the surroundings of large households, which has led to a lack of comparative material. The size of the household did not necessarily reflect the prevailing trends. The high material status of residents can be confirmed by the materials used to build households and objects inside. The best solution would be to compare homes by status rather than by location. Otherwise, the results may be affected by comparing, for example, households in capital cities with those in provincial areas.

\section{Discussion and Conclusion}

Estimated sizes of living space presented in the work of Cook (1972) and Cook and Heizer (1968) based on different data sets are $13.92 \mathrm{~m}^{2}$ (i.e. $2.32 \mathrm{~m}^{2} /$ person) for the first six inhabitants and $9.29 \mathrm{~m}^{2}$ for each additional person. In the case of luxury homes, the possibility that their owners could have had more space regardless of the number of people living in the property must be taken into consideration. The desire for more space could have derived merely from the human necessity to have more physical space and comfortable surroundings or it could also have been an expression of the social status of the owners. The size and luxuriance of the household could also be demonstrated by its location in the centre or better part of the city. Households from the Merkes district in Babylon and the households from Ur provide good examples. Taking into account the ethnographic research carried out by Joannes, Naroll and Cook Models, and Modern Household Research in Iraq' ${ }^{9}$ I assume that for each of the first seven members

9 Central Statistical Organization (CSO), http://www.cosit.gov.iq/ar/. 
of the family (the parents and 5 children) (Castel 1992: IO2) ${ }^{\mathrm{IO}}$ living space should equal around $40 \mathrm{~m}^{2}$ for each family member living in a luxury home; $20 \mathrm{~m}^{2}$ for each family member living in an average household and $8 \mathrm{~m}^{2}$ for each additional person in the same household. In cases where there is more than one family living in the household, this space should be doubled.

According to C. Castel (1992: 104) luxury homes are distinguished by such features as: floors, walls, plastered and painted, benches, as well as valuables: ivory elements, luxury ceramic production and cylindrical seals. The presence or absence of bathrooms, latrines, sewage installations and wells was also considered. Plans of households were evaluated in terms of the comfort of living, the existence of two courtyards (when both courtyards are to be recognised or whenever they are supposed to exist), the location of the rooms relative to each other (the presence of a room located on the southern axis, where there were private rooms or "main rooms").

The formula for calculating the number of inhabitants for "luxury homes" with a minimum floor space ${ }^{\mathrm{II}}$ of over $400 \mathrm{~m}^{2}$ :

$$
\text { NUMBER OF INHABITANTS }=\left(\text { LIVING SPACE }-\left(280 \mathrm{M}^{2}\right)\right) / 8 \mathrm{M}^{2}
$$

The above value of $280 \mathrm{~m}^{2}$ is the result of the following calculation: 7 (main family members) x 40 (area for each main family member).

The formula for calculating the number of inhabitants for "average households" with an area of less than $400 \mathrm{~m}^{2}$ :

$$
\text { NUMBER OF INHABITANTS }=\left(\text { LIVING SPACE }-\left(\mathrm{I} 4 \mathrm{O} \mathrm{M}^{2}\right)\right) / 8 \mathrm{M}^{2}
$$

The above value of $\mathrm{I} 4 \mathrm{O} \mathrm{m}^{2}$ is the result of the following calculation: 7 (main family members) x 20 (area for each main family member).

If the living area is $140 \mathrm{~m}^{2}$ or less, this means that this family did not have slaves or they did not live with them. In this case, the mathematical formula is as follows:

$$
\text { NUMBER OF INHABITANTS }=\text { LIVING AREA } / 7 \text { (FAMILY MEMBERS) }
$$

Based on the above formulas, the number of inhabitants in each household was calculated (calculations are presented in a separate diagram enclosed in this article) ${ }^{\mathrm{I} 2}$.

IO Another example of a household is bit Egibi, where the nuclear family consists of 8 members (Wunsch 1995-1996: 42-43).

II The smallest "luxury" household according to Castel (I992) has a living space of $400 \mathrm{~m}^{2}$.

I2 Total areas and households are determined on the basis of Miglus calculations (I999). 
When designating living space, it is essential to consider the issue of roof construction and the number of floors. Unfortunately, there is no relevant archaeological data on this subject. The highest remaining walls of households in Babylon reach a height of $2-2.5 \mathrm{~m}$ (Reuther 1926). It can be assumed that a roof with a flat structure was built of palm wood and clay ${ }^{\mathrm{I} 3}$. No remains of vaulted structures were found at the Neo-Babylonian sites (Miglus 1999: 186). Herodotus describes that there were mainly three or four floors in Babylonian households, but this description was not confirmed by evidence (Herodotus 2013: 80). O. Reuther (1926) found no signs of the upper floors, which was argued by the observation of multiple elevations of the floor; from the very beginning, ceilings were not build at a height of I.5 metres (Reuther 1926: 79f). A.H. Lenzen suggests that the stairs in Neo-Babylonian households were portable and stood between two walls (Lenzen 1962: 13 ). On the basis of this argumentation, we can make the assumption that most of the households were single-storey, as presented by Reuther (1926) in the case of the Merkes district.

One topic not often undertaken by researchers with regard to old residential buildings is that of demography and calculating the number of inhabitants in specific households. This is an interesting issue due to the lack of a direct and unambiguous relationship between the size of individual households and the number of their inhabitants. As mentioned earlier in this article, fewer residents could be present in large homes than one would expect, given the total surface area of these buildings. In smaller households, despite the small area, relatively many household members could live.

Despite the detailed research that has been published so far, there is no comprehensive approach to demographics of households from the NeoBabylonian period. The article comprises the first to collect and analyse many factors and dependencies taken into account by scientists, that resulted in one coherent image. In accordance with previously known calculation formulas, I made a new classification based on living space (in $\mathrm{m}^{2}$ ), whose purpose was to present the population of the household. This classification can be used as a basis for the division of households into "luxury" and "average".

I3 Reuther (1926) refers in this case to connections with the remains of roofs in the NeoBabylonian temple of Ishtar in Babylon. 
Tab. 1. Babylon - data on the area of households.

\begin{tabular}{|c|c|c|}
\hline & Total area $\mathrm{m}^{2}$ & Living space $\mathrm{m}^{2}$ \\
\hline $\begin{array}{l}\text { HOUSEHOLD I } \\
\text { (Fig. I) }\end{array}$ & 745 & 400 \\
\hline $\begin{array}{l}\text { HOUSEHOLD II } \\
\text { (Fig. 2) }\end{array}$ & 575 & 280 \\
\hline $\begin{array}{l}\text { HOUSEHOLD III } \\
\text { (Fig. 3) }\end{array}$ & I 475 & 822 \\
\hline $\begin{array}{l}\text { HOUSEHOLD IV } \\
\text { (Fig. 4) }\end{array}$ & 630 & 360 \\
\hline $\begin{array}{l}\text { HOUSEHOLD V } \\
\text { (Fig. } 5 \text { ) }\end{array}$ & 365 & I82 \\
\hline $\begin{array}{l}\text { HOUSEHOLD VI } \\
\text { (Fig. 6) }\end{array}$ & 260 & I3O \\
\hline $\begin{array}{l}\text { HOUSEHOLD IX } \\
\text { (Fig. 7) }\end{array}$ & 340 & 196 \\
\hline $\begin{array}{l}\text { HOUSEHOLD X } \\
\text { (Fig. 8) }\end{array}$ & 585 & 315 \\
\hline $\begin{array}{l}\text { HOUSEHOLD XI } \\
\text { (Fig. 9) }\end{array}$ & 200 & $\mathrm{IO} 3$ \\
\hline $\begin{array}{l}\text { HOUSEHOLD XII } \\
\text { (Fig. IO) }\end{array}$ & 235 & II 4 \\
\hline $\begin{array}{l}\text { HOUSEHOLD XIII } \\
\text { (Fig. II) }\end{array}$ & I90 & 89 \\
\hline $\begin{array}{l}\text { HOUSEHOLD E-I } \\
\text { (Fig. I2) }\end{array}$ & 315 & 169 \\
\hline $\begin{array}{l}\text { HOUSEHOLD E-2 } \\
\text { (Fig. I3) }\end{array}$ & 220 & IO7 \\
\hline $\begin{array}{l}\text { HOUSEHOLD AL-BAYATI } \\
\text { (Fig. I4) }\end{array}$ & I9I4 & 985 \\
\hline
\end{tabular}


Tab. 2. The results of calculations of the number of inhabitants according to the indicated formulas.

\begin{tabular}{|c|c|c|}
\hline Babylon & Type of household & $\begin{array}{l}\text { Maximum } \\
\text { number of inhabitants }\end{array}$ \\
\hline $\begin{array}{l}\text { HOUSEHOLD I } \\
\text { (Fig. I) }\end{array}$ & Luxury household & One family $+15^{\mathrm{b}}$ ) \\
\hline $\begin{array}{l}\text { HOUSEHOLD II } \\
\text { (Fig. 2) }\end{array}$ & Average household & Two families or one family +17 \\
\hline $\begin{array}{l}\text { HOUSEHOLD III } \\
\text { (Fig. 3) }\end{array}$ & Luxury household & $\begin{array}{c}\text { Three families or two families } \\
+33 \text { or one family }+68\end{array}$ \\
\hline $\begin{array}{l}\text { HOUSEHOLD IV } \\
\text { (Fig. 4) }\end{array}$ & Average household & $\begin{array}{l}\text { Two families }+ \text { Io or one } \\
\text { family }+28\end{array}$ \\
\hline $\begin{array}{l}\text { HOUSEHOLD V } \\
\text { (Fig. } 5 \text { ) }\end{array}$ & Average household & One family \\
\hline $\begin{array}{l}\text { HOUSEHOLD VI } \\
\text { (Fig. 6) }\end{array}$ & Average household & One family \\
\hline $\begin{array}{l}\text { HOUSEHOLD IX } \\
\text { (Fig. 7) }\end{array}$ & Average household & One family or one family +7 \\
\hline $\begin{array}{l}\text { HOUSEHOLD X } \\
\text { (Fig. } 8 \text { ) }\end{array}$ & Average household & $\begin{array}{l}\text { Two families }+4 \\
\quad \text { or one family }+22\end{array}$ \\
\hline $\begin{array}{l}\text { HOUSEHOLD XI } \\
\text { (Fig. 9) }\end{array}$ & Average household & One family \\
\hline $\begin{array}{l}\text { HOUSEHOLD XII } \\
\text { (Fig. IO) }\end{array}$ & Average household & One family \\
\hline $\begin{array}{l}\text { HOUSEHOLD XIII } \\
\text { (Fig. II) }\end{array}$ & Average household & One family \\
\hline $\begin{array}{l}\text { HOUSEHOLD E-I } \\
\text { (Fig. I2) }\end{array}$ & Average household & One family or one family +4 \\
\hline $\begin{array}{l}\text { HOUSEHOLD E-2 } \\
\text { (Fig. I3) }\end{array}$ & Average household & One family \\
\hline $\begin{array}{l}\text { HOUSEHOLD AL-BAYATI } \\
\text { (Fig. I4) }\end{array}$ & Luxury household & Two families +53 \\
\hline
\end{tabular}

a) The remaining living space does not have to be filled by slaves or additional residents, but the numbers shown in the results represent the maximum hypothetical number. The remaining surface area can always be used for other purposes.

b) The number itself will indicate that of people assumed to be slaves. 


\section{Bibliography}

Baker H.D. (2010), The Social Dimensions of Babylonian Domestic Architecture in the Neo-Babylonian and Achaemenid Periods, [in:] J. Curtis, S. Simpson (ed.), The World of Achaemenid Persia-History, Art and Society in Iran and Ancient Near East, I.B. Tauris, London, p. 79-194.

Baker H.D. (2015), Family Structure, Household Cycle, and the Social Use of Domestic Space in Urban Babylonia, [in:] M. Müller (ed.), Household Studies in Complex Societies (Micro) Archaeological and Textual Approaches, Oriental Institute of the University of Chicago, Chicago, p. 371-407.

Bayati A. al- (1985), The Babylonian Household, "Sumer", 41, p. 113-116.

Casselberry S.E. (1974), Further Refinement of Formulae for Determining Population from Floor Area, "World Archaeology", 6, p. 117-122, https://doi.org/10.1080/00 438243.1974 .9979593

Castel C. (1992), Habitat urbain néo-assyrien et néo-babylonien. De l'espace bâti a l'espace vécu, vol. I-II, P. Geuthner, Paris.

Cook S.F. (1972), Can Pottery Residues De Used as an Index to Population?, "Miscellaneous Papers on Archaeology", 4, p. 19-39.

Cook S.F., Heizer R. (1968), Relationship among Households, Settlement Areas and Population in Aboriginal, [in:] K.C. Chang (ed.), Settlement Archaeology, National Press Books, Palo Alto, p. 76-116.

Dohm K. (1990), Effect of Population Nucleation on Household Size for Pueblos in the American Southwest, "Journal of Anthropological Archaeology", 9 (3), p. 201-239, https://doi.org/10.1016/0278-4165(90)90007-Z

Fakri A.H. (1981), Demographic Archaeology, Academic Press, New York-London. Gurney O.R., Hulin P. (1964), The Sultantepe Tablets, vol. II, British Institute of Archaeology at Ankara, London.

Herodotus (2013), The Histories, trans. G. Rawlison, Roman Roads Media, LLC, Moscow, https://files.romanroadsstatic.com/materials/herodotus.pdf

Kolb C.C., Charlton T.H., DeBoer W., Fletcher R., Healy P.F., Janes R.R., Naroll R., Shea D. (1985), Demographic Estimates in Archaeology: Contributions from Ethnography on Mesoamerican Peasants, "Current Anthropology", 26, p. 581-599, https://doi.org/10.1086/203348

Laslett P. (1972), Introduction: the History of the Family, [in:] P. Laslett, R. Wall (ed.), Household and Family in Past Time, Cambridge University Press, Cambridge, p. 1-89, https://doi.org/10.1017/CBO9780511561207.003 
LeBlanc S. (1971), An Addition to Naroll's Suggested Floor Area Settlement Population Relationship, "American Antiquity”, 36, p. 210-211, https://doi.org/10.2307/278676

Lenzen A.H. (1962), Ausgrabungsberichte aus Uruk. Vorläufiger Berichte über die ... in Uruk-Warka unternommenen Ausgrabungen, Gebr. Mann, Berlin.

Matthews V.H. (2003), Marriage and Family in the Ancient Near East, [in:] K.M. Campbell (ed.), Marriage and Family in the Biblical World, InterVarsity Press, Downers Grove, p. 1-32.

Miglus P. (1999), Städtische Wohnarchitektur in Babylonien und Assyrien, von Zabern, Mainz am Rhein (Baghdader Forschungen, 22).

Naroll R. (1962), Floor Area and Settlement Population, "American Antiquity", 27 (4), p. 587-589, https://doi.org/10.2307/277689

Pfälzner P. (2001), Haus Und Haushalt, von Zabern, Mainz am Rhein.

Reuther O. (1926), Die Innestadt von Babylon (Merkes), Saarlänidsche Druckerei \& Verlag, Leipzig-Berlin (Wissenschaftliche Veröffenlichungen der Deutschen Orient-Gesellschaft, 47).

Schloen J.D. (2001), The Household of the Father as Fact and Symbol. Patrimonialism in Ugarit and the Ancient Near East, Eisenbrauns, Winona Lake (Studies in the Archaeology and History of the Levant, 2).

Sjöberg A.W. (1974), Der Examenstext A, "Zeitschrift für Assyriologie”, 64, p. 137-176.

Stol M. (1995), Private Life in Ancient Mesopotamia, [in:] J.M. Sasson et al. (ed.), Civilizations of the Ancient Near East, vol. I, Hendrickson, New York, p. 488-493.

Tenney J.S. (2010), Household Structure and Population Dynamics in Middle Babylonian Provincial "Slave" Population, [in:] L. Culberston (ed.), Slaves and Households, Oriental Intstitute of the University of Chicago, Chicago, p. 135-149.

Wetzel F., Weissbach. F. (1938), Das Hauptheiligtum des Marduk in Babylon, Saarlänidsche Druckerei \& Verlag, Leipzig-Berlin (Wissenschaftliche Veröffenlichungen der Deutschen Orient-Gesellschaft, 59).

Wiessner P. (1974), A Functional Estimator of Population from Floor Area, "American Antiquity", 39, p. 343-349, https://doi.org/10.2307/279593

Woolley C.L., Mallowan M.E.L. (1962), Ur Excavations 9. The Neo-Babylonian und Persian Periods, British Museum, London-Oxford-Philadelphia.

Wunsch C. (1995-1996), Die Frauen der Familie Egibi, "Archiv für Orientforschung", 42-43, p. 33-63. 


\section{Summary}

An Attempt to Calculate the Number of Inhabitants in Relation to the Social Dimension in Neo-Babylonian Residential Architecture on the Example of Babylon

In the article, I attempt to estimate the number of inhabitants of Neo-Babylonian households based on archaeological data based on the example of Babylon (Neo-Babylonian period: IIO0/IOOO-539 BCE). In order to discover how the household or an individual room was used, we must reconstruct the way that a household functioned. However, since no households can be found in archaeological research, it is necessary to turn to ethnographic sources. The article has been divided into three parts. The first part contains key information on households in the Neo-Babylonian period, indicated on the basis of ethnographic sources and compared with archaeological remains. In the second part of the article, I analyse various mathematical formulas used to calculate the number of residents on the basis of archaeological data. The third part comprises a discussion presenting my own mathematical formulas regarding the collected data.

Keywords: Babylon, house, household, Neo-Babylonian period, population, Merkes

\section{Streszczenie}

Próba obliczenia liczby mieszkańców względem wymiaru społecznego w nowobabilońskiej architekturze mieszkalnej na przykładzie Babilonu

W niniejszym artykule podejmuję próbę oszacowania liczby mieszkańców nowobabilońskich gospodarstw domowych w oparciu o dane archeologiczne i na przykładzie Babilonu (okres nowobabiloński: IIoo/ıooo-539 p.n.e.). W celu poznania sposobu wykorzystania gospodarstwa lub pojedynczego pomieszczenia należy zrekonstruować sposób funkcjonowania gospodarstwa domowego. $\mathrm{Z}$ uwagi jednak na to, że w badaniach archeologicznych nie uwzględniono zabudowań domowych, niezbędne jest zwrócenie się ku źródłom etnograficznym. Artykuł podzielono na trzy części. W pierwszej części zawarto najważniejsze informacje dotyczące gospodarstw domowych w okresie nowobabilońskim, uzyskane na podstawie źródeł etnograficznych i porównane z pozostałościami archeologicznymi. W drugiej części artykułu analizuję różne wzory matematyczne stosowane do obliczania liczby mieszkańców na podstawie danych archeologicznych. Trzecia część obejmuje omówienie przedstawiające moje własne wzory matematyczne odnoszące się do zgromadzonych danych.

Słowa kluczowe: Babilon, dom, gospodarstwo domowe, okres nowobabiloński, populacja, Merkes 
Ali al-lbadi, PhD student

University of Warsaw, Institute of Archaeology

e-mail: antoni.psh@gmail.com

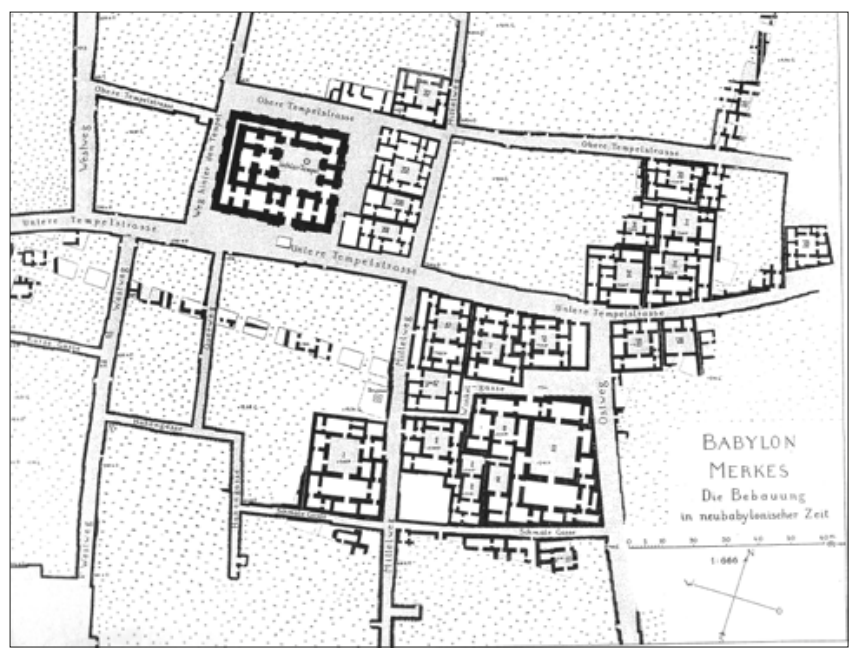

Merkes - residential area in ancient Babylon (Reuther 1926: Taf. 17).

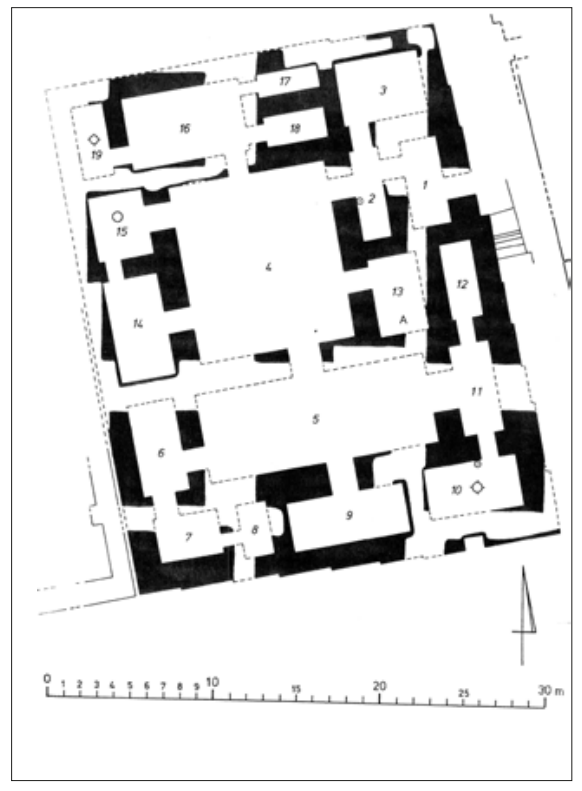

Fig. 1. Household I - courtyard according to the excavator (4), (Castel 1992, vol. II: pl. 19).

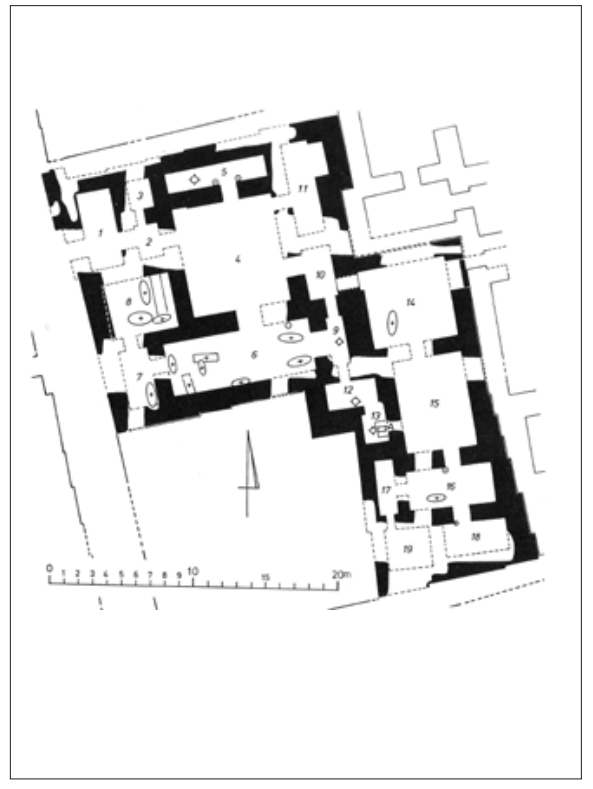

Fig. 2. Household II - courtyards according to the excavator $(4,15)$, (Reuther 1926: Abb. 66, 67, Taf. 17, 19). 


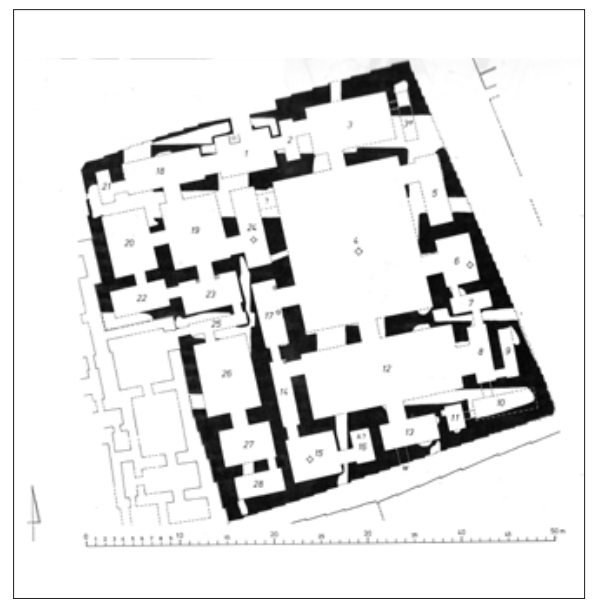

Fig. 3. Household III or the "Great Household" - courtyards according to the excavator (4, 19), (Reuther 1926: Abb. 68-70, Taf. 17, 19).

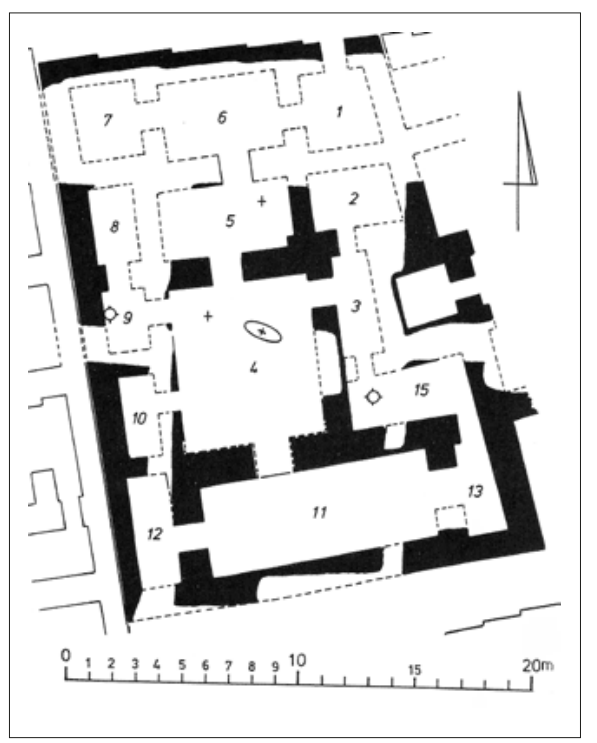

Fig. 5. Household V - courtyard according to the excavator (4), (Reuther 1926: Abb. 73, Taf. 17, 19).

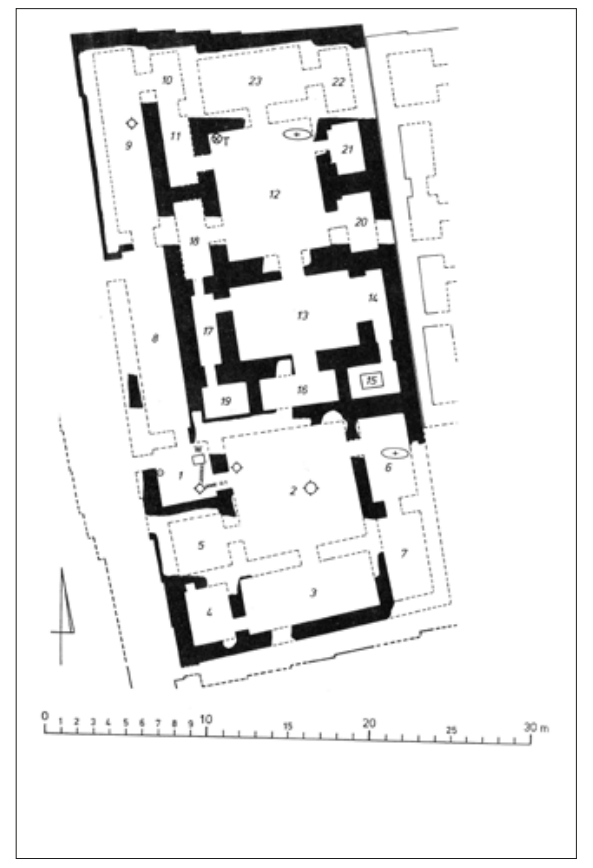

Fig. 4. Household IV - courtyards according to the excavator $(2,12)$, (Miglus 1999: Abb. 410).

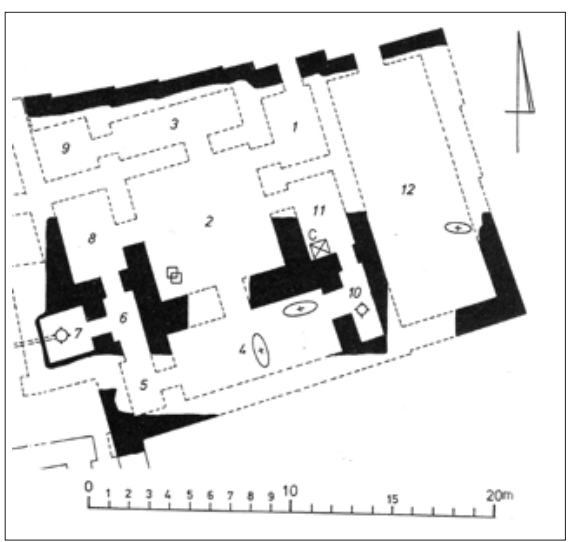

Fig. 6. Household VI - courtyards according to the excavator $(2,12)$, (Castel 1992, vol. II: pl. 29, b. 31). 


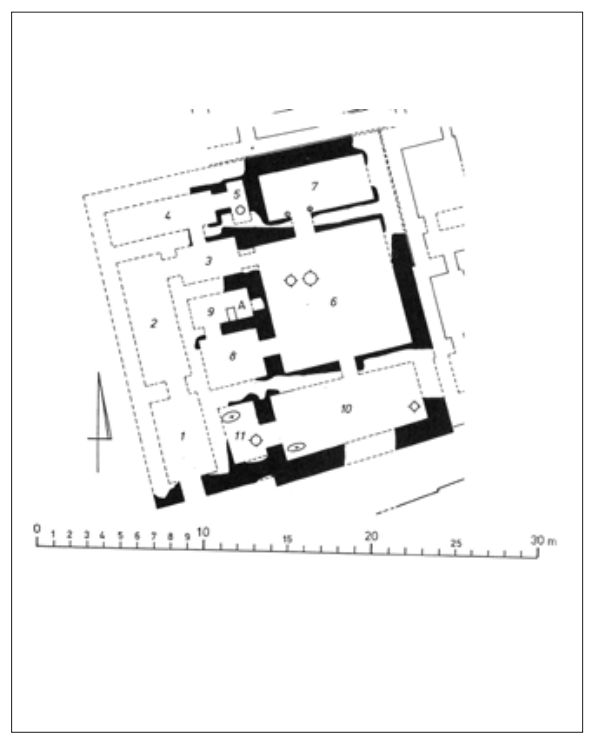

Fig. 7. Household IX - courtyard according to the excavator (6), (Reuther 1926: Abb. 77, Taf. 17, 20).

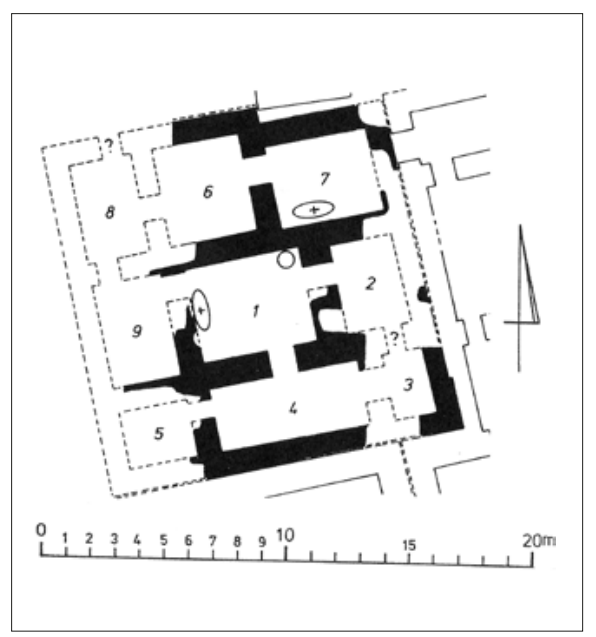

Fig. 9. Household XI - courtyard according to the excavator (1), (Castel 1992, vol. II: pl. 20, 35).

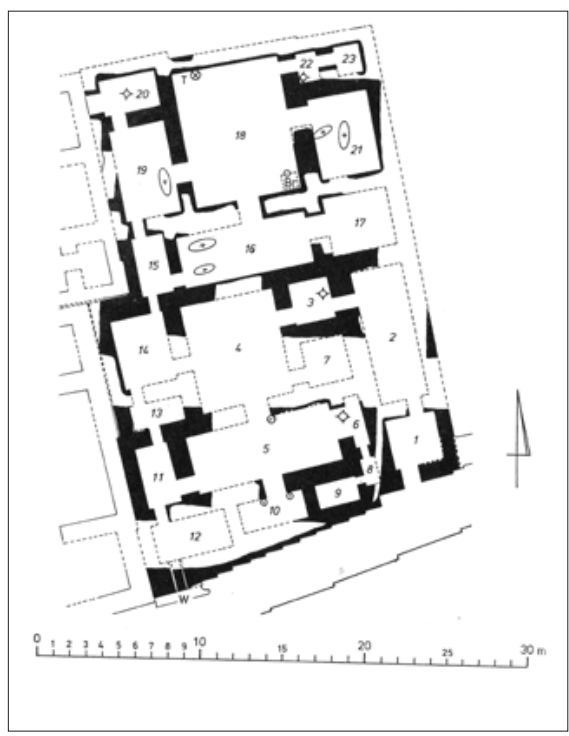

Fig. 8. Household X - courtyards according to the excavator $(4,18)$, (Miglus 1999: Abb. 411).

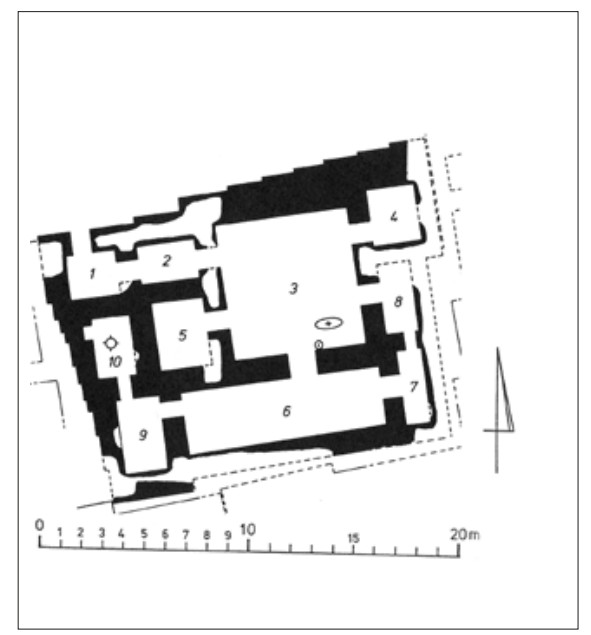

Fig. 10. Household XII - courtyard according to the excavator (3), (Reuther 1926: Abb. 81,82 , Taf. 17,20 ). 


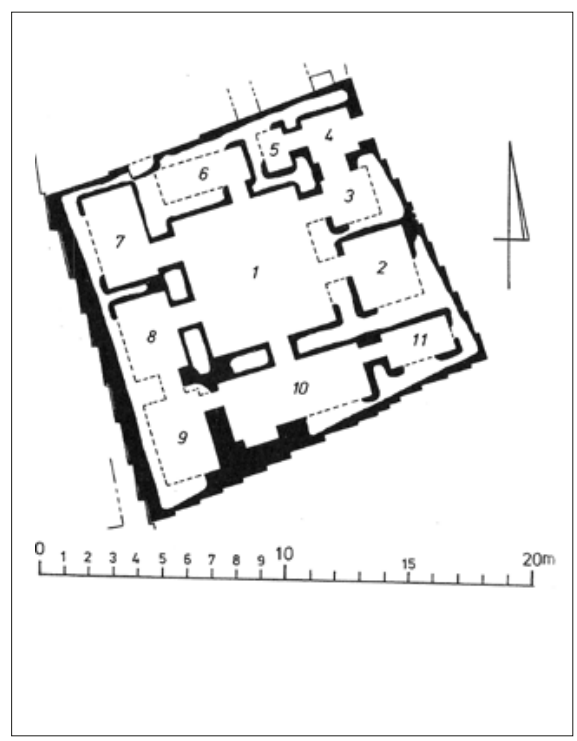

Fig. 11. Household XIII - courtyard according to the excavator (1), (Miglus 1999: Abb. 398).

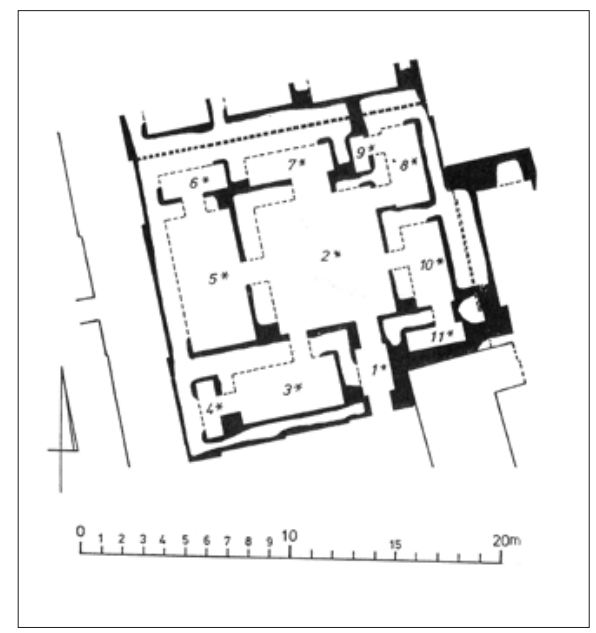

Fig. 13. Household E-2 - courtyard according to excavators (2), (Wetzel, Weissbach 1938: 18, Taf. 7).

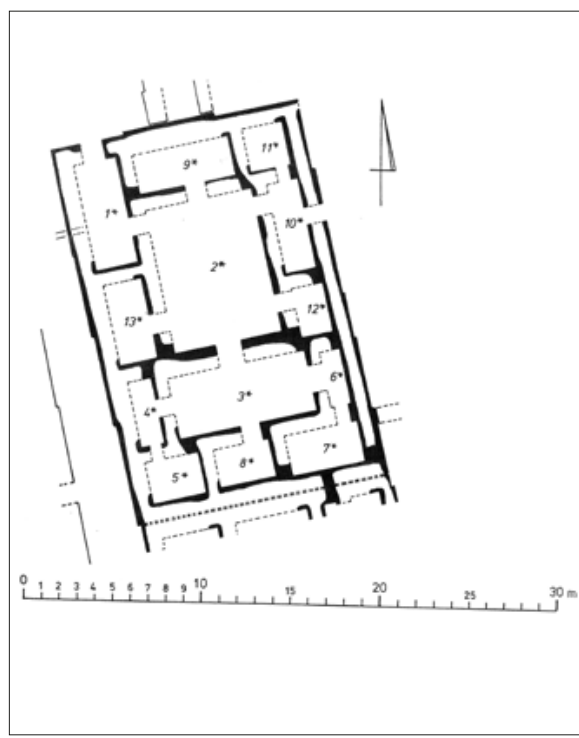

Fig. 12. Household E-1 - courtyard according to excavators (2), (Wetzel, Weissbach 1938: 18, Taf. 7).

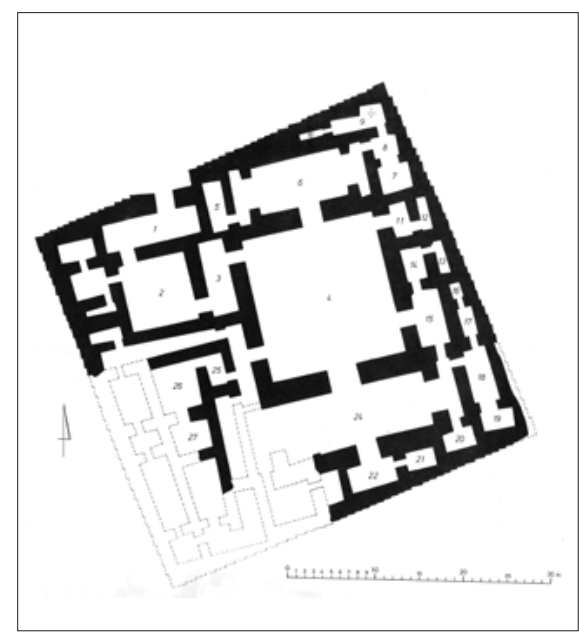

Fig. 14. Al-Bayati Household - courtyards according to the excavator $(2,4)$, (Al-Bayati 1985: plan 1). 